Burya A.

Tomina A.-M., Yeriomina Ye.

\title{
X-RAY ANALYSIS OF ORGANOPLASTICS BASED ON AROMATIC POLYAMIDE PHENYLONE
}

Об’єктом дослідження є міжмолекулярна взаємодія між в'яжучим та волокнистим наповнювачем, яка чинить великий вплив на триботехнічні та міцністні характеристики виробів з полімерних композиційних матеріалів. Враховуючи зазначене, визначення фізичної взаємодї між компонентами є важливою задачею при створенні нових композиційних матеріалів.

У роботі розглянуто виплив поліоксідіазольного (Оксалон) та полісульфонамідного (Танлон Т700) волокна на структуру ароматичного поліаміду фенілон марки C-1 за допомогою рентгеноструктурного аналізу. Аналіз досліджень показав, що введення хімічного волокна Оксалон призводить до впорядкування надмолекулярної структури в'яжучого: відбувається зменшення міжплощинної та найкоротшої міжатомної відстані на 18 і $25 \%$, при одночасному збільшенні середнього розміру кристалітів на $50 \%$.

Для органопластиків спостерігається зниження ширини дифузійного максимуму полімерної матриці в області кутів розсіювання 20-30 та зникнення другого аморфного гало в області кутів 40-60 пропориійне збільшенню конщентрачї̈ волокна в полімерній матриці. Причиною спостережуваного явища, очевидно, є ближньодіюча структуризація полімерних ланщюгів в'яжучого навколо волокна, в наслідок чого утворюються нові структурні елементи - фібрили у прикордонному шарі $і$ на межі поділу «матрицянаповнювач». При армуванні вихідного полімеру полісульфонамідним волокном Танлон Т700 спостерігається незначне зменшення міжплощинної та найкоротшої міжатомної відстані (на 5 \%) при збільшенні середнього розміру кристалітів на 13 \% у порівнянні з вихідним полімером. Отримані результати обумовлені тим, що фенілон і наповнювач мають близькі значення структурних характеристик, $i$, як наслідок, можна зробити висновок, що полісульфонамідному волокну притаманна аморфна структура.

На основі отриманих даних встановлено, що найкращими експлуатаційними властивостями буде характеризуватись органопластик, змічнений волокном Оксалон. Дані результати узгоджуються з проведеними раніше дослідженнями трибологічних характеристик. Це дозволяє рекомендувати даний композит для виготовлення деталей вузлів тертя машин і механізмів обладнання сучасної техніки натомість кольоровим металам та їх сплавам завдяки достатньо високим технічним характеристикам.

Ключові слова: поліоксідіазольне волокно Оксалон, полісульфонамідне волокно Танлон Т700, структура ароматичного поліаміду фенілон.

\section{Introduction}

In recent years, many polymer composite materials (PCM) have been developed, which along with non-ferrous metals and ceramics contribute to scientific and technological progress in all areas of modern technology - agricultural, automotive and metallurgical [1]. Among PCMs for structural and tribotechnical purposes, composites based on aromatic polyamides (AP) reinforced with various chemical fibers (CF) are of great interest [2]. The use of $\mathrm{CF}$ as a filler allows one to obtain PCM with high indices of tribological and physicomechanical characteristics, which in turn depend on the intermolecular interaction between the matrix and filler. The greater the interaction, the better the performance [3]. Therefore, it is relevant to study the relationship between performance and intermolecular interaction between a binder and a filler. Thus, the object of research is the intermolecular interaction between the binder and the fibrous filler, which has a great influence on the tribolotechnical and strength characteristics of products made of polymer composite materials. Given the above, the aim of research is studying the intermolecular interaction between the filler and the binder of organoplastics (OP) based on aromatic polyamide phenylone grade $\mathrm{C}-1$, reinforced with polyoxydiazole and polysulfonamide fiber.

\section{Methods of research}

Aromatic polyamide phenylone grade $\mathrm{C}-1$ (TU 6-05221-101-71) was selected as the polymer matrix for the creation of organoplastics. APM-based PCMs are characterized by high hardness, strength and stiffness, and stability of physical and mechanical properties at elevated temperatures (up to $523 \mathrm{~K}$ ) [4]. Organic fillers were chosen as filler: polyoxidiazole (Oxalon, Svetlogorsk Khimvolokno production, Belarus) and polysulfonamide (Tanlon T700, Shanghai production), the main properties of which are given in Table 1. The choice of fillers was determined 
on the one hand, its technical characteristics, and on the other hand, cheapness in the manufacture.

Preparation of OP based on phenylone containing 5-20 wt. \% CF (length 3-7 mm) was carried out by dry mixing in an apparatus with a rotating electromagnetic field $(0.12 \mathrm{~T})$ using ferromagnetic particles. Subsequently, the fractions were removed from the prepared compositions by magnetic separation. The mixtures thus obtained were formed into finished products by compression pressing.

Table 1

Properties of chemical fibers*

\begin{tabular}{|l|c|c|}
\hline \multirow{2}{*}{\multicolumn{1}{|c|}{ Indicator }} & \multicolumn{2}{c|}{ Value } \\
\cline { 2 - 3 } & Oxalon & Tanlon \\
\hline Density, g/cm ${ }^{3}$ & 1.43 & 1.42 \\
\hline Tensile modulus, GPa & 10.5 & 7.45 \\
\hline Elongation at break, \% & $19-24$ & $20-25$ \\
\hline Softening point, K & 723 & 640 \\
\hline Operating temperature, K: & 523 & 523 \\
- long; & 673 & 573 \\
\hline - short-term & 28 & 33 \\
\hline Oxygen Index, \% & \\
\hline
\end{tabular}

Note: ${ }^{*}$ - developed on the basis of data $[5,6]$

The processes of the interaction of Oxalon and Tanlon fibers with a polymer binder were evaluated using $\mathrm{X}$-ray diffraction analysis (XRDA) on a DRON-2.0 diffractometer (Russia) in a $\mathrm{CoK} \alpha$ monochromatic radiation $(\lambda=0.17890 \mathrm{~nm})$ in the range of angles $2 \theta$ from $10^{\circ}$ to $80^{\circ}$. The samples were mounted in standard quartz rings of the GP-12 attachment (Russia) with goniometric diffractometer equipment using plasticine. The series of the studied samples were shot in one mode, which made it possible to assess the structural characteristics. Interplanar $\left(d_{H K L}\right)$ and short interatomic distances $\left(R_{0}\right)$, average crystallite size $(L)$ of the initial polymer and OP based on it were calculated using the formulas given in [7].

\section{Research results and discussion}

Analysis of the diffraction patterns of phenylone and organoplastics based on it, reinforced with the Oxalon organic fiber (Fig. 1) shows the following. The structure of the initial polymer is amorphous (Fig. 1, curve 1), as evidenced by the presence of a pronounced diffuse maximum (halo) in the region of scattering angles of $20-30^{\circ}$ of X-ray radiation. In addition, the second, weakly pronounced diffuse maximum, characteristic of amorphous substances, is clearly manifested in phenylones on diffraction curves [8].

The introduction of fiber leads to a decrease in the width of the diffuse maximum of the binder, which is proportional to the increase in fiber concentration in the polymer matrix and the disappearance of the second amorphous halo (Fig. 1, curves 2-5). The reason for the observed phenomenon is obviously the short-range structuring of the polymer chains of the binder around the fiber, as a result of which new structural elements are formed - fibrils in the boundary layer and at the «matrix-filler» interface [9]. This is confirmed by a decrease in interplanar and short interatomic distances by 18 and $25 \%$, respectively, with an increase in the average crystallite size by $50 \%$ compared with the initial polymer (Table 2). This indicates the interaction between the binder and filler between the components.

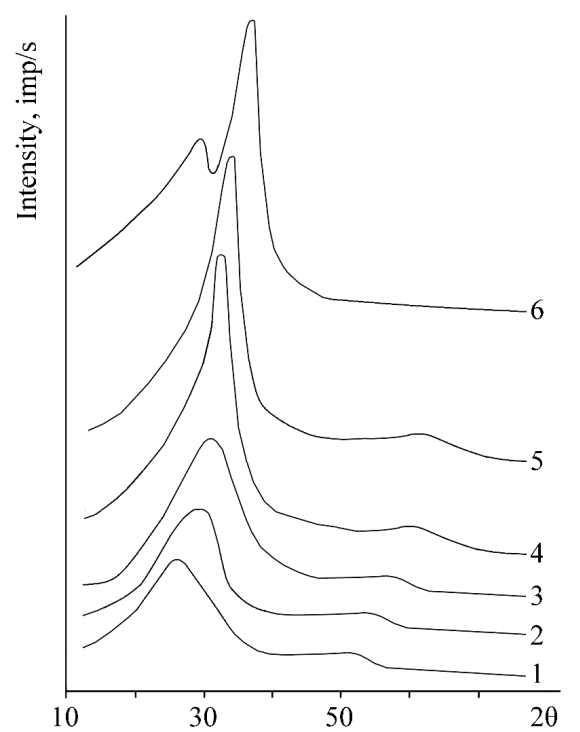

Fig. 1. Diffraction patterns of the initial polymer (1) and organoplastics based on it, containing 5 wt. \% (2), 10 wt. \% (3), 15 wt. \% (4), 20 wt. \% (5) Dxalon fiber (6)

Table 2

Results of qualitative and quantitative analysis of phenylone reinforced with Dxalon fiber

\begin{tabular}{|c|c|c|c|}
\hline Fiber content, $\%$ & $d_{\text {HKL, }} \mathrm{nm}$ & $R_{0, \mathrm{~nm}}$ & $L, \mathrm{~nm}$ \\
\hline 0 & 0.3976 & 0.4891 & 3.3664 \\
\hline 5 & 0.3456 & 0.4251 & 4.245 \\
\hline 10 & 0.3388 & 0.4125 & 5.0816 \\
\hline 15 & 0.3321 & 0.3961 & 6.0826 \\
\hline 20 & 0.3231 & 0.3676 & 6.8289 \\
\hline 100 & 0.2834 & 0.3486 & 10.492 \\
\hline
\end{tabular}

X-ray structural analysis of organoplastics reinforced with Tanlon fiber (Fig. 2) showed that the introduction of a filler leads to a slight decrease in interplanar. As well as a short interatomic distance (by $5 \%$ ) with an increase in the average crystallite size (by $13 \%$ ) compared with the initial polymer (Table 3). It is characteristic that the second diffuse maximum appears even at a sufficiently high (20 wt. \%) fiber concentration (Fig. 2, curve 5) in the studied compositions. This fact, as well as the preservation of the pronounced diffuse halo in the region of small angles of $20-30^{\circ}$ diffraction, indicates that the phenylone structure is amorphous for all the composites studied.

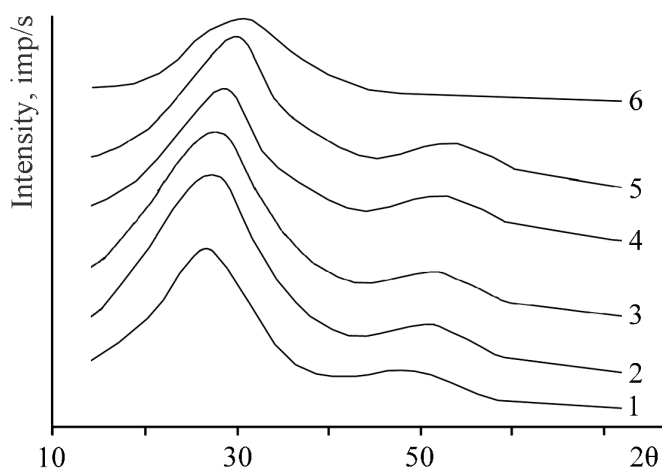

Fig. 2. Diffraction patterns of the starting polymer (1) and organoplastics based on it, containing 5 wt. \% (2), 10 wt. \% (3), 15 wt. \% (4), 20 wt. \% (5) Tanlon fiber (6) 
Results of qualitative and quantitative analysis of phenylone reinforced with Tanlon fiber

\begin{tabular}{|c|c|c|c|}
\hline Fiber content, \% & $d_{H K L}, \mathrm{~nm}$ & $B_{0, \mathrm{~nm}}$ & $L, \mathrm{~nm}$ \\
\hline 0 & 0.3976 & 0.4891 & 3.3664 \\
\hline 5 & 0.3867 & 0.4756 & 3.4421 \\
\hline 10 & 0.3832 & 0.4713 & 3.5120 \\
\hline 15 & 0.3787 & 0.4671 & 3.6663 \\
\hline 20 & 0.3746 & 0.4628 & 3.8203 \\
\hline 100 & 0.3697 & 0.4548 & 3.8400 \\
\hline
\end{tabular}

These results are due to the fact that phenylone and filler have a close chemical structure (Fig. 3, 4), and as a result, similar values of structural characteristics (which is confirmed by the experimental data given in Table 2). That is, the Tanlon fiber is characterized by an amorphous structure.<smiles></smiles>

Fig. 3. The chemical formula of phenylone [-1
Table 3

abe this effect. Given the above, it can be argued that the best representative performance properties will be characterized by OP based on phenylone reinforced with Oxalon fiber, which is confirmed by the experimental data [11, 12] conducted by the authors earlier.

\section{References}

1. Shvecova, O. A. (2016). Materialovedenie. Cheliabinsk: Izdatelskii centr IuUrGU, 239

2. Ershova, O. V., Ivanovskij, S. K., Chuprova, L. V., Bahaeva, A. N. (2015). Modern composite materials based on the polymer matrix. International Journal of Applied and Basic Research, 4, 14-18.

3. Kulagina, G. S., Korobova, A. V., Il'ichev, A. V., Zhelezina, G. F. (2017). Physical and physico-mechanical properties of antifriction organoplastics based on combined fabric filler and epoxy binder. Proceedings of VIAM, 10 (58), 69-78.

4. Kataeva, V. M., Popov, V. A., Sazhin, B. I. (Eds.) (1975). Spravochnik po plasticheskim massam. Moscow: Khimia, 568.

5. Fiber materials. Tanlon. Available at: http://en.tanlon.com.cn/ Products/fms/ Last accessed: 11.10.2018

6. Perepelkin, K. E. (2009). Armirujushhie volokna i voloknistye polimernye kompozity. Saint Petersburg: NOT, 380.

7. Burya, A., Yeriomina, Ye., Rybak, T. (2016). X-ray phase analysis of metal polymers based on aromatic polyamide. Scientific journal of TNTU, 3 (83), 116-121.

8. Kargin, V. A., Slonimskii, G. L. (1967). Kratkie ocherki po fiziko-khimii polimerov. Moscow: Khimia, 232.

9. Lipatov, Yu. S. (1977). Fizicheskaia himia napolnennyh polimerov. Moscow: Himia, 304

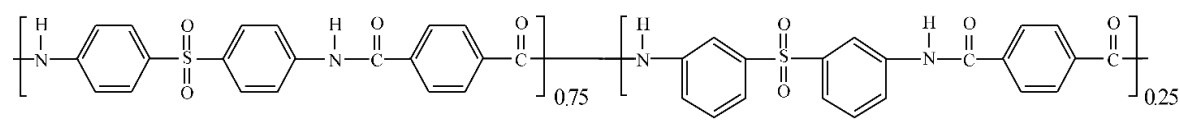

Fig. 4. The chemical formula of Tanlon fiber

The obtained results of the structural analysis are in good agreement with the indicators of the tribological characteristics of these OPs. As is known [10], the increase in PCM wear resistance is associated with the improvement of the supramolecular structure of the binder, that is, the transformation of the globular structure into fibrillar. So, organoplastic reinforced with Oxalon fiber is characterized by better tribological properties compared to Tanlon [11, 12].

\section{Conclusions}

Based on the obtained results, it is found that reinforcing phenylone with Oxalon CF promotes structural rearrangement of the polymer in the presence of a filler: new structural elements - fibrils - are formed in the boundary layer and at the «matrix-filler» interface. The use of polysulfonamide fiber as a filler does not allow
10. Kargin, V. A., Slonimskii, G. L., Sogolova, T. I. (1966). Sviaz nadmolekuliarnoy struktury s mehanicheskimi svoystvami polimerov. Proceedings from 22nd Annual Technical Confetreal, $12,43$.

11. Burya, A. I., Tomina, A.-M. V., Chernov, V. A. (2016). Effect of fiber on oksalon tribological characteristics organic plas-tics based on phenylone C-1. Problems of tribology, 82 (4), 11-16.

12. Burya, O. I., Tomina, A.-M. V. (2017). The effect of heatresistant polysulfonamide fiber on the tribological properties of organoplastic based on phenylone C-1. Problems of tribo$\log y, 85$ (3), $76-80$.

Burya Alexandr, PhD, Professor, Department of Condensed Matter Physics, Dniprovsk State Technical University, Kamenskoe, Dnipropetrovsk region, Ukraine, e-mail: ol.burya@gmail.com, ORCID: http:// orcid.org/0000-0001-5448-2728

Tomina Anna-Mariia, Researcher, Department of Condensed Matter Physics, Dniprovsk State Technical University, Kamenskoe, Dnipropetrovsk region, Ukraine, e-mail: an.mtomina@gmail.com, ORCID: http://orcid.org/0000-0001-5354-0674

Yeriomina Yekaterina, Senior Researcher, Department of Condensed Matter Physics, Dniprovsk State Technical University, Kamenskoe, Dnipropetrovsk region, Ukraine, e-mail: eka.yeriomina@gmail.com, ORCID: http://orcid.org/0000-0001-8595-5735 rence: Technical papers SPE. Mon- 